\title{
IMPROVING STUDENT'S VOCABULARY MASTERY THROUGH EARLY HEALTH EDUCATION VIDEO AT PRADNYANDARI I KINDERGARTEN
}

\author{
Si Putu Agung Ayu Pertiwi Dewi, Ni Komang Purwaningsih \\ STIKES Bina Usada Bali \\ gungayoe@gmail.com,purwaenglishlecturer@gmail.com
}

\begin{abstract}
This research is a classroom action research on improving English vocabulary in kindergarten students through health education video. The purpose of this study is to find out the improvement of English vocabulary through early health education video. The results of this study indicated an increase in English vocabulary through the health education video on preschool students of Pradnyandari I Kindergarten. The research method is classroom action research Data collection techniques are observation, documentation (,) interviews (,) and a collection of English words about dental and oral health through early health education video. This research was conducted in 3 cycles. The results showed an increase in vocabulary ability in English through early health education video on Pradnyandari I Kindergarten. The increase in the first cycle was $40.65 \%$, in the second cycle $48 \%$ and a significant increase of $65.9 \%$ was in the third cycle. It can be concluded that the increase in vocabulary through early health education videos is effectively implemented to students of Pradnyandari I Kindergarten.
\end{abstract}

Keywords: English, vocabulary, health education video

\section{INTRODUCTION}

Early childhood education is education that is held to develop personal, knowledge, and skills that underlie basic education and develop themselves as a whole in accordance with the principle of education as early as possible and the source of life. Aspects developed in early childhood education are aspects of behavior with habituation including social, emotional, independence, moral and religious values, and the development of basic abilities, which include language development, cognitive, art, and motoric physical. Early age is the golden age, therefore education at this time is a very fundamental education and is very decisive for future child development. If children get a good stimulus, then all aspects of children's development will develop optimally. Therefore early childhood education must be able to stimulate all aspects of a child's development both behavioral, linguistic, cognitive, artistic and motoric.

Language acquisition in early childhood includes 2 stages, first language acquisition and second language acquisition (foreign language). First language acquisition is a language that is acquired and understood by children in life and communicating in their environment. The first language is often also called mother tongue, because the child first interacts and learns with the mother. Second / foreign language is the child's language obtained after the first language. The second language of Indonesian children is generally Indonesian and foreign languages. Indonesian language acquisition is obtained by children in their living environment 


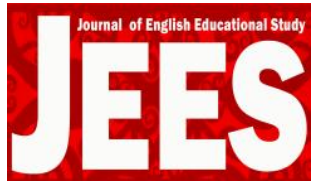

Journal of English Educational Study

Volume 2 Issue 2 November 2019 Page 106-112

E-ISSN: $2655-0776$

and formal education. Whereas foreign language acquisition is generally obtained through informal and formal education

The development of vocabulary languages in early childhood is greatly increasing along with the increasing development of science and technology. At this time electronic media can be used as a learning media to develop the acquisition of vocabulary in children through video that feature cartoon shows, games, stories, films that are not only oriented towards the development of education but also related to children's health. The video content of English and health education is very beneficial for children and parents. Besides being able to raise vocabulary in children indirectly, it can make it easier for parents and educators to deliver health education to children on the importance of oral and dental health through the video entitled "how to brush their teeth properly".

Basic knowledge and awareness of early health is very important to know for elementary school-aged children who generally need regular health care and health supervision while being in school. School-age children are very often negligent in maintaining their health, especially their oral and dental health. This happen as the cause of unhealthy snacking and lack of attention to maintaining their health.

In Pradnyandari I kindergarten, the students are expected to develop according to the developmental stage but to improve the acquisition of English language skills most have not used the appropriate technique, it seems the teacher is still using conventional methods namely by giving examples orally and students are asked to repeat story that has been delivered. This is due to the lack of use of the media as a source of learning for children. Based on the preliminary study also, there was a big problem of dental and oral health. The snacking habit as the cause of the health problem on student. More than $52 \%$ students eat candy and chocolate after meals. It Based on the limitation of the problem above, the formulation of the problem in this research is how to improve student's vocabulary mastery through early health education video at Pradnyandari I Kindergarten

\section{ENGLISH VOCABULARY}

Humans in social certainly will not regardless of verbal or non verbal language because through human language human needs will be achieved or fulfilled easily. A scientist said that your language is the limit from your world, the point is when people master many languages then with free he will go well in digging science as well as being businessman. Rusefrinaria in (Huda et al 2017) said that period the most speech and language development intensive in humans lies in the age early, precisely in the three years of his life, namely a period in which the human brain develop in the process of achieving maturity. Then based on the description above 
it can be concluded that language is very important foundation for stepping out, hanging out / socializing, digging knowledge and make it easier to relay success in all fields, by therefore language is very important to learn starting from childhood so later it will be easier to dig information especially in English.

\section{HEALTH EDUCATION VIDEO}

According to Harmer (Dewi, 2013) said teachers use pictures or graphics taken through books, newspapers, and magazines or photography to facilitate learning. Images can be flashcards, large pictures on the wall, photography, special text books. Some teachers also use projector slides and videos. Images of Whole can be used in various ways such as the following:

a. Drills: with the lowest grade student grade, flashcards are specifically used to sort grammar as different sentence cues and practice grammar

b. Communication: pictures are very useful for various communication activities. Teachers often use pictures for writing creativity. They want to tell students a story by using at least three pictures in front of the class. He can convey to students to make a specific conversation about the topic of the picture.

c. Understanding: the most suitable way to use an image is to explain and analyze its meaning. In this case, it can be easier for teachers to know students' abilities of understanding through media images.

d. Ornamentation: various types of images are often used to make the work more interesting. for example reading texts which are decorated with photographs are very necessary such as in magazines, newspapers and articles because this can attract students 'interest in the class besides the teacher can have the power to unite the students' minds.

e. Prediction: pictures are very useful for giving predictions to students about what topics will be the next lesson. Students can see pictures and try to interpret what is seen. This is very beneficial to involve students in an assignment

f. Discussion: pictures can provide simulated questions, such as what is shown, what is felt, what is meant and so on. By providing simulations like that the instructor can ask students to write a description of the picture

Based on the opinion above it can be concluded that the use of animated media images or videos in teaching and learning is very effective because the images can facilitate teachers to provide figure to students about an event. This health education video is a 
cartoon video entitled "how to brush your teeth properly". This video shows the steps in brushing teeth properly, information about bad and health snack, healthy dental and oral, and the name of the equipment

\section{METHOD}

The approach used in this study is an action research with classroom action research method that studies quantitative data from its applied linguistic aspect. Qualitative approach is a research procedure that produces descriptive data in the form of written and oral words from people or observed behavior. The analysis used in qualitative research is more descriptive in nature, which means the interpretation of the contents is made and arranged systematically or thoroughly and systematically.

Population is the total member of research subject (Arikunto, 2012). The population of this study is the entire students age 5-6 years of Class A Pradnyandari I Kindergarten. It is located in Kerobokan Village, Badung Regency. The number of population are 45 students. The sample is a part of population which will be investigated Therefore, this class will be chosen as the sample of study in order to investigate the vocabulary understanding through early health education video.

The analysis technique used in analyzing the research data to prove the hypothesis that has been formulated. In this classroom action research analysis is based on the results of observations of learning activities as well as the results of the actions taken. Analysis of data from observations of teachers as executors of learning activities is used to reflect, so researchers can determine actions that can be taken in the next cycle. The steps for obtaining student observation data are (1) adding up the scores achieved by the child on each item of observation, (2) Making a tabulation of observation scores increasing the English vocabulary through video consisting of numbers, student's names, item numbers observation, number of scores, (3) Calculating the percentage increase in children's English vocabulary through video

The data taken in this study is creativity data and free drawing implementation data. The instruments used include (1) observation sheets for improving English vocabulary, (2) observation guideline sheets improving English vocabulary through early health education video, (3) interviews are used to determine children's abilities before actions and efforts made by researchers to improve English vocabulary through early health education video. 


\section{FINDING AND DISCUSSION}

This study aims to improve the ability of English vocabulary on students in Pradnyandari I Kindergarten. Before taking action on first cycle, the researchers made observations and conducted pretests. In the pretest, the researcher starts with a question and answer session with students. From the results of the pretest the average English vocabulary of the students was $40.65 \%$. This can be seen from the majority of students who have not been able to understand the English vocabulary of "bathroom" material so that they need the teacher's help to answer it. For example, when students are given English material on this bathroom topic. Students are only given questions without displaying pictures or visuals of the tools of bathroom to be asked. This makes it difficult for students to guess the word in question. Based on the results of observations, the researchers felt the need to improve the ability of English vocabulary for student of Pradnyandari I Kindergarten. On this cycle the word that are easily remembered by the students are toothbrush, toothpaste, towel, tissue, soap. The word that are hard to remember are jug, bucket, mop. On the observation, there are many English vocabularies that are not know by the students and they don't understand the meaning.

In the second cycle of treatment, researchers doing opening, apperception, introducing media by showing a health education video with the title "how to brush your teeth". This video show begins with a song with the aim of providing a stimulus to students to focus on listening to video shows. The content in this video contains vocabulary about dental and oral health education. Example video fragment as below

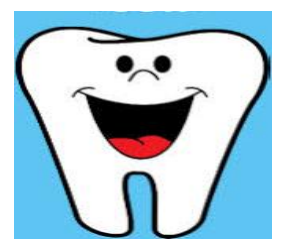

Figure 1

In this video show containing pictures of teeth then followed by its pronunciation tooth / tu: $\theta$ / repeated three times then followed by students. This repetition aims to clarify the words and help students to remember. Tooth image is showed then pronounced its pronunciation (tooth / tu: $\theta /)$.

The results of this second cycle showed that students began to be interested in watching video shows and were active in the activities provided by researchers. On the observation there are several students experience trouble in pronoun English vocabulary, some students who are 
less focused in learning process, but it can be overcome when the song video is playing. They become more comfortable. At the end of this cycle session, the researcher opens the question and answer session by showing the video again by showing the pictures. In this question and answer session, the results of $48 \%$ of students were able to answer the questions given by the researcher. On the interview result, most of student said that they interest to study english by video. Because the result of the second cycle have not been achieved, then the next cycle is necessary.

The implementation of the third cycle is posttest, in general the implementation of this cycle is almost the same as the second cycle, on the opening students are shown a video containing the song about "how to brush your teeth" then slowly the students are able to follow. Here is the lyrics of the song's lyrics brush your teeth, nice and clean, clean your teeth in between, brush your teeth up and down, scrub your teeth round and round ."At the time of this video show, students seemed more enthusiastic about singing this song than the previous cycle. This is because students have been able to repeat the song. Then students are shown the same video again. In between vocabulary engagements, students are given an understanding of the importance of maintaining oral health. In the final session, students were invited to practice how to brush their teeth with instructions in English accompanied by the teacher and also health workers. Furthermore, the researcher re-opened the question and answer session and gave rewards to students who were able to answer the researcher's questions. The results of the third cycle showed that students 'enthusiasm increased when they competed to answer the researchers' questions. From this activity the researchers observed and calculated the average percentage increase in English vocabulary through an early health education video reaching $65.9 \%$. This means there is a significant increase in English vocabulary. From the interview result of students, they really liked learning method using audio visual media like this early health education video. In addition to student, the result of interviews with the teachers in Pradnyandari I Kindergarten stated that they become more creative in conveying learning using video. They are also more motivated to increase all scope development by using interesting media. 


\section{CONCLUSION}

Based on the results of the class survey conducted by researchers at Pradnyandari I Kindergarten in three learning cycles, it can be concluded that improving vocabulary through early health education videos is effective. This is indicated by an increase in the mean percentage in the first cycle is $40.65 \%$. In the second cycle it was $48 \%$ and in the third cycle it increased significantly to $65.9 \%$. The use of media such as video early health education in an effort to improve students 'English vocabulary is a fun learning method because it can open students' understanding and early awareness of the importance of health

\section{REFERENCES}

Arikunto dkk. 2012. Penelitian Tindakan Kelas. Jakarta:Bumi Aksara

Cameron, D. (2001). Teaching Language to Young Learners. Cambridge: Cambridge Press.

Decarrico, J. S. (2001). Vocabulary Learning and Teaching. Teaching English as A Second for Foreign Language. 3 rd edition (M. Celce. Murcia ed). Boston, MA: Heinle and Heinle

Dewi, SPAAP.(2013).Kemampuan Menulis Recount Text Dengan Menggunakan Teknik Picture Series Pada Kelas Viii Di Smp Angkasa Kuta Badung. Bali: Udayana

Harmer, Jeremy. 2007. The Practice of English Language Teaching. Cambrigde : Longman.

Hurlock, EB. 1993. Perkembangan anak. Jilid I. Jakarta. Erlangga

Ida Vera Sophya Pembelajaran Bahasa Inggris Pada Anak Usia DiniLinguistics Development Project.

Muharmis, 2007. Perkembangan Kemampuan Berbahasa Anak TK. Pekanbaru. Dinas Pendidikan

Sudaryanto. 1993. Metode dan Teknik Analisis Bahasa. Jakarta: Indonesian

Yusanti, Naskah Publikasi ( Peningkatan Penguasaan Kosa Kata Bahasa Inggris Melalui Media Audio Visual Pada Anak Uia 4-5 Tahun di Pos PAUD Dahlia Vii Desa Pondok Kecamatan Grogol Kabupaten Sukoharjo0 Tahin 2011/2012

Zuriah, N. 2006, Metodologi Penelitian Sosial dan Pendidikan: Teori-Aplikasi. Jakarta: Bumi Aksara. 